\title{
Achievements and barriers to Vietnam's economic development
}

\author{
Phu-Hop Mai ${ }^{1,2,{ }^{*}, \text { Jun-Wu Yang }}{ }^{1}$, Thi-Van Nguyen ${ }^{3}$ \\ ${ }^{1}$ College of public management, Hunan Normal University, Changsha, China \\ ${ }^{2}$ School of Political Science, Can Tho University, VietNam \\ ${ }^{3}$ College of Business Administration, Hunan University, Changsha, China
}

\section{Email address:}

mphop@ctdu.edu.vn (P. H. Mai), yangwyf@aliyun.com (J. W. Yang), kimfabaco@gmail.com (T. V. Nguyen)

\section{To cite this article:}

Phu-Hop Mai, Jun-Wu Yang, Thi-Van Nguyen. Achievements and Barriers to Vietnam's Economic Development. International Journal of Economics, Finance and Management Sciences. Vol. 1, No. 6, 2013, pp. 374-381. doi: 10.11648/j.ijefm.20130106.24

\begin{abstract}
The research with the introduction of Vietnamese economy achievements since the Government implemented the reforms for the removal of the Centrally Planned Economy into the market economy so that legal system is improved to attract the investment as well as the support of the international community. Moreover, the article also analyzes the barriers which prevent the Vietnamese economy from developing its fully potential strength.
\end{abstract}

Keywords: Industrialization, Poverty Reduction, Local Ideology, Vietnam

\section{Introduction}

A period time after the liberation, the effectiveness of the Vietnamese economy and the limited economic relations revealed. Therefore, the economy felt down into the serious crisis. Vietnam conducted, in the text, the innovation which officially launched in 1986. Since then, Vietnam has made a lot of the significant breakthrough. The first is known as the innovation in the economic thinking with the change from the Centrally Planned Economy into the oriented-socialism market economy. Besides, there are industrialization and modernization of the country, diversification and multilateralization of the external economic relations, open-door performance and international integration etc.

It was the reform that helped Vietnam reduce the poverty situation quickly and initially create the industrialized economy with the achievements of the economic growth as well as the relative equality in the society. The Law on foreign investment in 1987 was the first legislation document, makes to create the legal framework of the market economy in Vietnam. In 1991 the law on private business and Business Law was issued. The amended Constitution of 1992 affirmed the existence and development of the multi-sector commodity economy under the market mechanisms and the foreign investment sector. There was then a series of the important laws of the market economy formed in Vietnam, such as the Land Law, Tax Law, Bankruptcy Law, Environment Law, Labor Law, and hundreds of the ordinances as well as the decree of the Government issued to specify the implementation of these laws for the socioeconomic development. Along with the legislation, the market institutions in Vietnam have also been gradually formed. Government has eliminated the centrally planned system, emphasized on the relation between the goods and the currency with the focus of the economic management measures, established a range of financial institutions, banks and the basic markets, namely the currency markets, labor markets, commodity markets, land markets etc. The Administrative Reform is motivated to improve the competitiveness of the economy, create the favorable environment which is more than sufficient for business operations and bring all resources into effectiveness for the economic growth. The Administrative reform strategy in the period 2001-2010 was regarded as the determination of the Vietnamese Government with the emphasis on the modification of the administrative procedures, legislation, and economic management mechanism to create the effective institution for the demand of the national development in the new period. Furthermore, the goal of 2020 tends to develop as the basic modern industrialized economy. The instability of the economic development was, however, caused by the challenges to the economy, namely the partial area, group's benefits, lack of the business philosophy as well as the prestige, the administrative system with the existing shortcomings etc. 
The research with the introduction of Vietnamese economy achievements and also analyzes the barriers which prevent the Vietnamese economy from developing its fully potential strength. The authors proposed solutions to overcome such barriers.

\section{Achievements of the Vietnamese Economy after the Reform}

Vietnam has implemented the national reform since 1986, and over two past decades of innovation; there have been a lot encouraging achievements in the initial phase. Vietnam has created the market economic environment which is more competitive and active than ever. The multi-sector commodity economy was encouraged to develop with the efficiency of the mobilization of social resources for economic growth. The external economic relations became more open to attract more foreign direct investment, expand the export markets and further develop a number of operation areas for the growing revenue of the foreign exchange such as tourism, labor export, remittances reception.

In the period 1986 - 1990: This was known as the first stage of the renovation. The policy of the multi-sector economic development with the operation under the oriented-socialism market. The economy gradually overcame the shortcomings to develop. After the implementation of 5-year plan (1986-1990), there were a lot of significant achievements at first: GDP increased by $4.4 \%$ per year, the total value of the agricultural production increased an average of $3.8-4 \%$ per year; the industry $7.4 \%$ per year, in which the production of consumer goods increased by $13-14 \%$ per year; export value went up $28 \% /$ year [1]. The successful performance of the three development target programs of foods, the consumer goods and exports making recovered, economic growth, inflation restriction, etc., that is recognized as the remarkably initial success to specify the socialist industrialization in the first stage. The most important thing is that this is the basic transition from the former mechanisms into the new management mechanism with the innovation process of socio-economic life to initially release the productive force for the new growth motivation.

In the period 1991 - 1995: The economy gradually got out from the recession. The economy continuously gained a lot of the important achievements: overcoming the recession, the growth rate being relatively high, constant and comprehensive, most major targets being over: GDP on average grew by $8.2 \%$ per year; the industrial production went up by $13.3 \%$ per year; the agriculture by $4.5 \%$ per year; the services by $12 \%$ per year, total 5-year production (1991-1995) reached 125.4 million tons, up $27 \%$ in comparison with the period 1986-1990 [2]. Most economic sectors also gained the relative growth rate. "Vietnam was out of the serious socio-economic crisis which lasted over 15 years. In spite of instability in some aspects, the necessary foundation was created to change into the new period of development: improvement of industrialization and modernization" [3].

In period 1996 - 2000: This period marked the important development step of the economy, the improvement of the industrialization, and modernization. Despite the impact of the regionally financial - economic crisis (period 1997-1999) as well as the serious natural calamity and severe challenges, however, Vietnam constantly gained a relatively high growth rate. The average GDP in the period 1996 - 2000 was $7 \%$, in which the agriculture, forestry and fisheries sector increased by $4.1 \%$, the industry and construction by $10.5 \%$; the service by $5.2 \%$ [4]. "If in the whole period $1991-2000$, the average GDP growth rate was by $7.5 \%$. The GDP in 2000 increased twice as much as that in 1990" [5].

In the period 2001 - 2005: The renovation at this stage entered into the deep level. The implementation of socio-economic development strategies in the period 2001 2010 and 5-year plan in the period 2001-2005 approved by the IX Congress has gained the certain achievements. The growth rate of economy was quite encouraging year after year. The average GDP growth was $7.5 \%$ per year, particularly in 2005 by $8.4 \%$, in which the agriculture increasing by $3.8 \%$, the industry and construction by $10.2 \%$, the service by $7 \%$. Particularly, the scale of the economy's domestic product in 2005 reached 837.8 trillion twice as much as that of 1995 . GDP per capita is about 10 million (equivalent to 640 USD) exceeding the average of the developing countries with low income (500 USD) [6]. Beginning with the condition of the food deficit, 50 thousand to 1 million tons of food was imported annually; Vietnam has become a major rice exporter in the world. In 2005, Vietnam ranked first position of the world's pepper export and second position of the rice, coffee, cashew, the forth in rubber; etc.

Along with the economic growth, the macroeconomic stability which maintained for the stability of politics, society, defense and security initially promoted the advantages of the economy, each region and sector had the economic institutional reforms with the gradual improvement of policies as well as the efficiency of finance, currency. The human forces have been developed together with the advanced science and technology, etc.

In the period 2006 - 2010: The economy's growth rate maintained relatively high. As the potential scale economies, Vietnam escaped from the underdevelopment beginning with the country having the low income into the average income (low). Average 5-year GDP reached 7\%. Despite the impact of the financial crisis and the global recession (from the end of 2008), the foreign investment was still high. Total FDI was nearly $\$ 45$ billion, over $77 \%$ in comparison with the plan. Total newly-registered capital was estimated to increase by 150 billion USD 2.7 times as much as the plan and 7 times as much as the period 2001-2005. Total committed ODA gained over 31 billion USD 1.5 times as much as its target; disbursement estimated at 13.8 billion USD, exceeding 16\%. GDP in 2010 calculated at current 
prices at 101.6 billion U.S., 3.26 times as much as in 2000 [7].

In 2011, despite the economic recovery after the global financial crisis was still very slow, the average annual economic growth, however, remains at $7 \%$ per year. The rate was, however, lower than plan $(7.5 \%-8 \%)$, it was still more highly appreciated the average of the regional countries [8].

Therefore, within 20 years (1991-2011), Vietnamese GDP growth at $7.34 \%$ per year reached the highest in Southeast Asia, in particular in Asia and the world in general, the economic scale in 2011 was 4.4 times as much as in 1990 , 2.1 times as much as in 2000 (the period from 2001 to 2011 on average at $7.14 \%$ per year) [9].

In 2012 , GDP grew by $5.03 \%$ compared to 2011 , although growth rate was lower $(5.89 \%$ in 2011$)$, in the context of the world economy was in trouble, this is a reasonable growth rate. Regarding agriculture, forestry and fisheries, the estimated growth rate increase by $3.4 \%$ compared to 2011 , increased by $4.8 \%$ compared to 2011 in industry. Consumer price index rose by $6.81 \%$ in 2012 . The development and investment increased by $7 \%$ compared to the previous year and accounted for $33.5 \%$ of GDP. Import and export of goods increased by $18.3 \%$ [10]. Export turnover might exceed 100 billion dollars, turnover rate of Import and export compared to GDP in 2011 was approximately $170 \%$, ranking the fifth in the world. Implemented FDI capital from 1988 to January 7, 2012 was 96.6 billion dollars compared to over 236 billion dollars registered. ODA capital from 1993 until now committed nearly 80 billion dollars, disbursed over 35 billion dollars [11].

Besides the general difficulties of the world economy, economic growth rate in the first 6 months of 2013 in Vietnam reached $4.9 \%$, according to a forecast by the Centre for Economic and Policy Research (VEPR) economic growth rate reached $5.3 \%$ in 2013 [12].

In general, the sectors of the economy developed comparatively, in which the stable development of agriculture, especially food production has ensured national food security, industrial products had more and more abundant and diverse development in species, quality was improved, gradually increased competitiveness and ensured the supply and demand of the economy, maintained domestic market and expanded export market; focused on developing and investing a number of new industries, high-tech, service sector with stable growth. The considerable recovery and growth created solid grounds to gained more solid results in the implementation process of 5 year plan (2011-2015) in the next years.

Along with high growth rates of GDP, the economic structure had a significant change. From 1990 to 2012, the proportion of agriculture area has declined from $38.7 \%$ to $17 \%$ gave way to an increase in the proportion of industry and construction area from $22.7 \%$ up to $41.64 \%$, while in the service sector, the proportion was $38.6 \%$ in 1990 and $41.36 \%$ in 2012 [13]. Quality of products was increasingly high. The structure of the service area changed in the direction of increasing the proportion of service industries with high quality such as finance, banking, insurance, travel...

Agriculture had an important change; it shifted from single crop rice with low productivity and large shortages into the agriculture which is not only enough to domestic use, but also for export with large quantity, ranked the second position in the world, contributing to the international food security, export of coffee, rubber, cashew nuts, pepper, seafood, ranked one of the largest exporters in the world.

The service sector has grown more diversely; meeting the production and life demands: tourism and telecommunications developed with a rapid rate, the financial services, banking, legal advice, developed in the direction of progress and efficiency.

Results implemented well the economic development undertakings with lots of components, better promoted the potential of the sectors.

State Economic sorted innovated, improved quality and efficiency, more focused on key sectors and key areas of the economy. Management mechanisms of State enterprises were innovated an important step towards abolishing subsidies, the implementation of the company's model, the autonomy and responsibility promotion of enterprises in business. Private economy developed powerful, better mobilized the resources and potential of the people, and was an important force to promote growth and economic development. In 2012, the private sector contributed about $50 \%$ of GDP [14]. Economy with foreign investment's growth rate was relatively high, becoming an important component of the national economy, contributing $18.97 \%$ of GDP (2011) [15]. Is an important bridge to the world of technology transfer, international traffic, contributing to the state budget and creating jobs for many people.

Socialist-oriented market economy Institution gradually formed, macroeconomic was basically stable.

It can be said that the great success impressively of Vietnam over 25 years of innovation has effectively solved the relationship between economic growth and cultural development, implemented progress and social justice, the development opportunities opened to all economic sectors, all classed of the population; positiveness, activeness, creativeness of people were improved. In which, the most significant was jobs resolution, poverty reduction, good results achievement, beyond the Millennium Development Goals of the United Nations. The World Bank has assessed the rate of poverty reduction in Vietnam dropped from $60 \%$ to $20.7 \%$ for 20 years (1990-2010) with approximately 30 million people. Besides, Vietnam also achieved impressive achievements in education and health. Enrollment ratio of the poor in primary education was more than $90 \%$ and in the middle school was $70 \%$ [16].

To achieve achievements of 25 years of innovation, Vietnam amended to complete the system of legal, policy and operational mechanisms of the market economy which was built comparatively synchronous, emphasized efficiency. Operation of business types in the multi-component economy and management apparatus of 
the State innovated into an important step. With positive undertakings and active integration of international economy, economic relations between Vietnam and other countries; international organizations will be increasingly expanded.

Vietnam joined the Association of Southeast Asian Nations (ASEAN), made the commitment to ASEAN - Free Trade Area (AFTA), Trade Agreement between Vietnam the United States; join World Trade Organization (WTO). Up to now, Vietnam had trade relations with over 200 countries and territories, signed more than 90 bilateral trade agreements with other countries, creating a new important development step in foreign economics'

Socialist-oriented market economy Institution continued to develop and improved; policies, the renewal of the party continued to be institutionalized into laws, mechanisms and policies more and more completely, more synchronously; environment of investment, business improved, market factors and the market types continued to establish, develop; multi-component economy has significantly grown.

The consolidation of the corporation, the pilot established state corporations achieved several results. In a Period 2006 - 2010, the number of enterprises increased by 2.3 times; the capital increased 7.3 times compared to the period 2001-2005. Enterprises became popular forms of business organization.

Next to the internal development, the biggest success of Vietnam government in the past was always implementation of social reforms, creation of airy legal environment for foreign attraction along with other countries' aid capital. After 20 years (1993-2013), the community of international donors have pledged to support Vietnam with official development assistance (ODA) amounted to nearly 80 billion dollars [17]. This important amount was such a "catalyst" contributing to change the face of the country.

In recent years, Vietnam created favorable conditions and ways to attract Foreign Direct Investment (FDI) which was the support source for development and was one of the important sources to offset the lack of foreign currencies, foreign capital and will be a "boost" to develop the country. Foreign investment capital increased over time, from 20.67 billion U.S. dollars, accounting for $24.32 \%$ of the total social investment capital (1991-2000) to 69.47 billion U.S. dollars, accounting for $22.75 \%$ of the total social investment capital (2001-2011). The proportion of foreign-invested sector in the economic structure of the period 2000 - 2011 increased $5.4 \%$.

The first important benefit FDI brought to Vietnam today is the modern transfer of science and technology, professional technique, advanced management level. When investing in particular country, investor not only invests capital but also capital and objects such as machinery and equipment, fuels and materials.... intellectual scientific, managerial know-how, market access capacity... Thus, in the long term this is the most basic benefits for Vietnam. FDI can promote the development of new jobs, especially those jobs requiring higher levels of technology. Therefore, it has great impact on the process of industrialization and economic structural shift. FDI brings management experience, business skills and technical proficiency for domestic partners through training programs and learning-by-doing process. FDI also brings to Vietnam the complicated knowledge of production while receiving the technology of countries. FDI also promote Vietnam to try to train qualified engineers, managers to participate in joint ventures with foreign.

The second benefit FDI brought to Vietnam is promoted economic growth and international integration. Obviously, activities of foreign direct investment have contributed actively to promote economic development in Vietnam. FDI is a prerequisite, a basic to exploit the enormous potential for the development of domestic economy.

FDI also accelerate the process of economic structural shift. Foreign direct investment is one of the important parts of foreign economic activity. The country will participate more in the international division of labor. For integration into the economy between the countries in the world, requiring each country to change the economic structure of domestic in accordance with the international division of labor. The shifting economic structure of domestic in line with the general level of the world will create favorable conditions for foreign investment. In contrast, the investment activities contribute to accelerating the process of economic structural shift. Because: Firstly, through the activities of foreign direct investment has appeared in many areas and new sectors in the host country. Secondly, foreign direct investment helps rapidly develop technical and technology level in many economic sectors, contributing to the increase of labor productivity in some sectors and increase its share in the economy. Thirdly, some sectors are stimulated to develop by foreign direct investment, but also many sectors eroded away, and then come to be erased.

In addition to the above effects, foreign direct investment contributes significantly to the state budget revenues through the payment of investment units and the proceeds from the lease of land.

Foreign direct investment also contributes to improve the international balance of Vietnam because most of the projects of foreign direct investment is the production of export-oriented products; the contribution of foreign capitalist and the development of export is very large. Along with the ability to increase exports of goods, foreign direct investment also expanded the market both at home and abroad. The majority of foreign direct investment projects have the plans of consuming products.

Socially, foreign direct investment has created many new jobs attracted a considerable amount of employees working in units of foreign investment. It contributes significantly to reducing unemployment.

However, besides these accomplishments, foreign direct investment has also negatively affected when Vietnam tries to attract:

To receive more inappropriate techniques. Foreign companies often transfer old and out of date technology and 
machinery. This is shown by the fact of investing in sugar factories, cement factories... In fact, technology transfer situation of industrialized countries to developing countries is also a critical issue. For example, according to the report of American Development Bank, 70\% equipment of the Latin American countries imported from developed capitalist countries is outdated technology. Similarly, the case of technology transfer, ASEAN at first has no experience of testing so that it has been received many disadvantages. However, this side also partly depends on the technology policies of the host countries. For example, Mexico has 1800 assembly and production factories of transnational companies of the United State. Some factories are moving to Mexico to avoid the strict regulations on environment in U.S. and taking advantage of loopholes in environmental laws of Mexico.

For the ecological environment pollution, the foreign companies have been forced to protect the environment in accordance with strictly regulations in industrialized countries. Through foreign direct investment they want export environment to countries that coercive measures, environmental protection laws are not effective.

The dependence on economic for host countries of foreign direct investment often mainly due to transnational companies, the company will increase the dependence of the economy, technique and consumption of goods network of transnational companies. Foreign direct investment contributes important additional capital for the process of economic development and implementation of technology transfer. Also through transnational companies are foreign partners o that we can consume goods because these companies hold most of the goods consumed channel from one country to another. Therefore, if increasingly rely on foreign direct investment; the dependence of the economy on the industrial countries will develop better and if the economy relies heavily on foreign direct investment, its development will be a false prosperity. The prosperity got by other things of other people.

In order to attract FDI, Vietnam to adopt a number of incentives for investors as tax reduction or exemption in a long time for the majority of foreign investment projects or reduction for land lease, factories...

On the other hand, the purpose of the investors is to make a profit so that they only invest in the most beneficial location. Thus, the amount of FDI has increased the imbalance among regions, between rural and urban. This imbalance can cause political instability or FDI could also cause adverse impacts on social.

\section{The Barriers for Economic Development in Vietnam Today}

In addition to achievements due to the open policies and focused on efficiency also arise the negative phenomena that impede economic development and social.

\subsection{Local Ideology Is One of the Risks to Reduce the Development and Distrust of People and Investors}

Local ideology is a clear manifestation of the pragmatic in business of Vietnam today. It is expressed in many different forms, rich and diverse. Many locals do not care about the general interest and by many ways to take national capital to their locals causing wastage investment, the development and integration reduction.

Many places at the same time to draw up plans to build ports from national sources. After finishing, the plan does not promote effective because in fact, it does not eligible to form large-scale ports in the plan at their local. There are also cases superior or investor wants to build welfare work such as the bridge or health facilities... at a commune. It is reasonable to put the work in this position but Chairman or Secretary of commune who is in other hometown so that he wants to take the investment to his hometown without the agreement of investor. Finally, the people with the highest responsibility of commune to lose investment opportunity to the unit in charge.

In any form, this local interest still conflicts with the common interests of the nation. It is also a major obstacle to effectively promote the country's resources to develop economic and resolve social problems.

The trend for local interests is held in many sectors, other sectors of the economy. This is the main reason causing a series of plans broken. Nearly 20 years, Vietnam develops in mass the ports, cement, tiles, sugar factory and economic areas... and the movement of building airport is also conceived. Instead of cooperation, assignment to promote the strengths of each locality, the investment of constraining among localities has led to a situation of competition, cancel each other out.

Ports, for example have the fragmented investment in small-scale, the small harbor interwoven with large harbor in unreasonably way is one of the major shortcomings of Vietnamese seaport system. Vietnam currently has 30 seaports with 166 harbors, 350 docks with a total length of $45,000 \mathrm{~m}$. Throughput capacity of about 350-370 million tons/year. Except for some new harbors built and put into operation from 2006 is equipped with modern cargo handling equipment, the remaining mostly use common equipment with outdated technology. The average capacity of general stevedoring in Vietnam only about $50 \%-60 \%$ compared to ports in the region [18]. Commodities less than the reception capacity of ports has led to a phenomenon that many ports are ready to reduce the price of port services. The reduction of port services in this abnormal condition did not create incentives for market competition but pulled the mutual benefit of most of enterprises for port exploiting goes down and the risk of stop working some ports. The prolonged loss of joint venture poses a risk to the position of Vietnam in the partner relationship. However, It must recognize objectively that the harbor capacity exceeded the actual volume of goods in the early years of putting port in operation is quite normal. 
The damage, in this case, is not only to plan, investment program of provinces and sector but also directly to economy. Inflation and macroeconomic instability is an inevitable result of waste of investment capital and resources of the country.

The really worrying issue is the local welfare problem which has crept into the state management bodies of the Ministry level. If the provinces and cities are impatient with the local economy and make wrong decisions to break the plan, even if the interest groups are dominating, there is still hope for the supervision and correction from higher management level. But when the ministry level itself is also dominated by local interests, the consequences will be far more serious. Here, besides the economic loss, the local interest status also makes the management coordination among the ministries and sectors become more difficult, thereby negatively affect the services for people and businesses which causes negative issues such as bribery and corruption.

Today, we often say much about integration, international labor division, and participation in global value chain. But even in the country, the localities, ministries, and sectors have not yet cooperated with one another to form the overall value chain, in order to develop their full potential and strength of the nation for economic development. Certainly, Vietnam will not be able to integrate and participate effectively in the global labor division chain when the phenomenon of local interests.

This thought also affects the labor division. The local interest thought is considered a big challenge for young officials when they come and work in poor communes. In fact, may officials and people in the communes share their opinions that: The commune has several thousand of people; why do they send an official from somewhere else here? They do not believe in the qualification and enthusiasm of young officials; they do not care and support the young officials to fulfill their missions. In addition to the expression "disregard young people", "do not accept strange persons" in the example above, the local "disease" is also expressed in the disregard for common benefits, only find the ways to bring about benefits to their locality, authority, and family, although such acts are not appropriate. It is also expressed in the think way "one official benefits the whole family". When the family has a person with "high position", he finds ways to "take care" of the family, relatives, and the locality, which affects the rights and good benefits of the mass.

This is the clearest evidence to show that local thought affected deeply, and for long time in the subconscious mind, words, and actions of many officials and even people in the remote areas. This "disease" was clarified in resolution 4 of the XI Communist Party of Vietnam: "Some urgent issues of Party building at present": "a considerable number of officers and Party members including those who hold leadership positions, managers, and senior officers have degraded political ideology, ethics, way of life with the various manifestations of fading ideology, selfish, individualism, pragmatism, rush for money, titles, corruption, waste, arbitrary, and become unscrupulous..." [19].

The harmful effects of local thought are very clear, small scale hindered the development of one or some individuals; large scale affects the benefits of the nation and the people. It is time to implement more drastic measures to stop local thought by rotating officials; appointing officials from a locality to undertake key position in the People's committee in different locality, regular monitoring, inspection, detection, treatment and strictly address the local expression...

From local thought and local interests, the trend of group benefit was formed, which develops, erodes, and reduces the people's trust in the Party and State, then affects the sustainable development of country. Group interests make the spirit of cooperation, mutual support in the Vietnamese business and entrepreneur community become limited. The lack of solidarity, loose and temporary relationship among businesses is a shortcoming in economic operation. The private interests leads to the "opportunity stealing" business situation "do business on their own", which make the Vietnamese businesses lack competitiveness compared with foreign partners. For example, in rice and agricultural product exportation, Vietnamese businesses "do business on their own", with no links and lack of community spirit. Thus the foreign businesses could decide the prices. Some businesses operate seasonally; they do not invest to build warehouses so that they have to sell the goods at low prices, which affect the overall exportation floor and cause loss for the farmers and the country.

\subsection{In Addition, the Lack of Support and Cooperation, and Focusing Too Much on Immediate Interests and Local Interests Makes Vietnamese Businesses Lack Business Philosophy and Long-Term Business Strategy, So that the Development Is Not Sustainable}

According to the international economic experts "the majority of Vietnamese enterprises do not have long-term business strategy and business philosophy" [20]. At the moment, the majorities of Vietnam enterprises, especially small and medium enterprises only focus on immediate profits, short-term vision, and limited market orientation, usually sell out the products and do not care about the market demand.

\subsection{Because of Focusing on Intermediate Benefits, the Credibility Becomes a Barrier of Vietnam Economy}

Vietnamese Society is still the society lacking credibility. Trust and credibility are absent. For trust, they have to rely on family factors or through blood. This is one of the big shortcomings in creating the image of a favorable business environment in Vietnam [21].

Because it lacks credibility, the competition will be unfair despite their dignity; fraud, deceit, anger, illicit, regardless of human life and longevity of ethnic races are not prevented 
and pushed back [22]. The violation of regulations on food hygiene and safety is an alarming matter. For high profits, many businesses and individual households use the harmful chemicals in processing and preservation, which seriously affects public health. For example, people use toxic substances to process food, such as 3-MCPD at high content to produce soy sauce, and formaldehyde to make noodles, rice noodle cake, Rhodamine $\mathrm{B}$ to color melon seeds, and industrial color to make chili powder, etc Cases of food poisoning because the businesses lack of business ethics and accountability for the community is still popular in Vietnam.

In business relations with foreign partners, Vietnamese businesses hardly obtain the credibility. Many shipments are returned due to the quality. The breach of trust adversely affects the Vietnamese businesses.

Due to lack credibility as well as for benefits and because the law of Vietnam is not strict, many investors often make violations of environmental issues. Currently, Vietnam has hundreds of industrial parks which are discharging waste into the environment, according to statistics, only 40 industrial parks have completed collective wastewater treatment system, 20 industrial parks are investing in construction or preparing to construct the collective wastewater treatment system, and the remaining Industrial parks do not have this system [23]. However, some enterprises have waste treatment system but only operate them when the state authorities make the inspection, and use obsolete equipment and technologies, which leads to the environmental crisis, almost all the rivers are contaminated, and may streams become dead rivers which seriously affect the utility and health of the people.

\subsection{In Addition to the Limitations, the Administrative Procedure Is One of the Big Barriers for Investment Attraction and Socio-Economic Development}

Since the Scheme 30 by the Prime Minister on administrative reform is implemented, the reform of administrative procedures has achieved encouraging results. According to the Department of administrative procedure control (Ministry of Justice), from 2011 to June 2013, the ministries and departments have completed the simplification of 3,606 administrative procedures out of 4,751 administrative procedures approved by the Government at 25 Resolutions.

In particular, in the field of investment and business, along with the improvement of policies and institutions to ensure the increasing requirements of the implementation of the tasks of socio-economic development while facing the difficulties and challenges arising from the impacts of the economic crisis and recession, the administrative procedures in fields of land, tax, customs, and business registration... also gradually simplified, more practical and closer to international practices. However, the progress in the reform of administrative procedures has not met the set requirements, especially for attracting investment in the current period. Besides the achievements, we should frankly recognize that, the reform and simplification of administrative procedures in general, and in business investment in particular still has limitations and shortcomings; the administrative procedures are still cumbersome, complex, high fees; negative issues arise (such as bribery) which hinders investment and business activities of not only domestic investors but also foreign investors .

\section{Limited Remedies}

To promote the achievements and to remove the intermediate difficulties Vietnam government and businesses need to perform the following tasks:

1. Resolutely eliminate local ideology construct and perfect the legal systems in the direction of transparency, simplicity, and fairness advantages to attract investment across regions. The State should closely manage to attract investment to locals based on the laws. Need to plan industry investment for sentinel regions are associated with the resource consumption market... To promote the administrative reform, improve the state management efficiency, create a favorable investment environment, stepping up anti- corruption.

2. Influence of culture, lack of investment for production and business. Thus enterprises only focus on immediate profits, short-term vision, and limited market orientation. To resolve this problem, the government has policies, preferential programs to support as the credit guarantee and credit assistance for businesses However, the receipt of this capital is limited due to the lack of information, the complicated procedures, the interest rate are not appropriate Therefore we need to speedily remove these obstacles. To create favorable conditions, simple procedures, and have fairness in order to the firms could receive these supports.

3. To build the credibility in business, the business must obey the laws, besides, they have to be aware the absolute value of the confidence in the business and must to build the abilities to make exactly what they promise. To be aware of the absolute value of the confidence in the business, the businessmen should be thinking the services. That is to always put them in the position of consumers and self-evaluation of their products in an objective way based on the amenities and benefits.. In the business, the conscientious attitude and honesty will create the trust. And it's a competitive advantage need to confirm.

4. Besides, continue to improve the efficiency of administrative procedures to match international practices. To continue to improve the efficiency of foreign affairs to take advantage of the international community's supports.

\section{References}

[1] Võ Hồng Phúc. 2006. Những thành tựu về kinh tế - xã hội qua 20 năm đổi mới (1986 - 2005), trong Việt Nam 20 năm đổi mới. Nxb Chính trị quốc gia, Hà Nội. trang 141. (Vo, H.P. 2006. The achievements on economic- social over 20 years of innovation (1986 - 2005), in" Vietnam in 20 years of innovation, National Politic Publisher. Pp 141) 
[2] Võ Hồng Phúc. 2006. Những thành tựu về kinh tế - xã hội qua 20 năm đổi mới (1986 - 2005), trong Việt Nam 20 năm đổi mới. Nxb Chính trị quốc gia, Hà Nội. trang 143. (Vo, H.P. 2006. The achievements on economic- social over 20 years of innovation (1986 - 2005), in" Vietnam in 20 years of innovation, National Politic Publisher. Pp 143)

[3] Đảng Cộng sản Việt Nam. 1996. Văn kiện Đại hội đại biểu toàn quốc lần thứ VIII, Nxb. Chính trị quốc gia - Sự thật Hà Nội, trang 12. (Communist Party of Vietnam. 2006. Document of the 8th National Congress, National Politic Publisher - The Truth, Hanoi. Pp 12).

[4] Võ Hồng Phúc. 2006. Những thành tựu về kinh tế - xã hội qua 20 năm đổi mới (1986 - 2005), trong Việt Nam 20 năm đổi mới. Nxb Chính trị quốc gia, Hà Nội. trang 144. (Vo, H.P. 2006. The achievements on economic- social over 20 years of innovation (1986 - 2005), in" Vietnam in 20 years of innovation, National Politic Publisher. Pp 141)

[5] Đỗ Thị Thảo, Nguyễn Thị Phong Lan. Những thành tựu cơ bản về phát triển kinh tế - xã hội của Việt Nam từ khi đổi mới đến nay. Tạp chí Cộng sản 26/5/2013 ( Đỗ, T.T- Nguyen, T.P.L. The fundamental achievements of economic development - socio innovation from Vietnam until now. Journal of Communist. 26/5/2013)

[6] Võ Hồng Phúc. 2006. Những thành tựu về kinh tế - xã hội qua 20 năm đổi mới (1986 - 2005), trong Việt Nam 20 năm đổi mới. Nxb Chính trị quốc gia, Hà Nội. trang 146. (Vo, H.P. 2006. The achievements on economic- social over 20 years of innovation (1986 - 2005), in" Vietnam in 20 years of innovation, National Politic Publisher. Pp 146)

[7] Đảng Cộng sản Việt Nam. 2011. Văn kiện Đại hội đại biểu toàn quốc lần thứ XI. Nxb Chính trị quốc gia, Hà Nội, trang 151. (Vietnam Communist Party. 2011. Documents of the 11th National Congress, National Politic Publisher, Hanoi, Pp 151)

[8] Chinh phu Vietnam. 2012. Báo cáo Tình hình kinh tế - xã hội năm 2011, kế hoạch phát triển kinh tế - xã hội năm 2012 và 5 năm 2011 - 2015. (The Vietnam government. Report of Economic - social situation in 2011, plan for economic social development in 2012 and 5 years 2011 - 2015).

[9] Dương Ngọc. 2012. Kinh tế Việt Nam: 67 năm qua các con số. http://vneconomy.vn/2012083112062680P0C9920/kinh-te-v iet-nam-67-nam-qua-cac-con-so.htm. (Duong, N: Vietnam Economy: 67 years through numbers).

[10] Tổng cục Thống kê, Bộ Kế hoạch và Đầu tư. 2012. Số liệu thống kê kinh tể - xã hội năm 2012. (General Department of Statistics, Ministry of Planning and Investment. socio-economic Statistical data - 2012).

[11] Dương Ngọc. 2012. Kinh tế Việt Nam: 67 năm qua các con số. http://vneconomy.vn/2012083112062680P0C9920/kinh-te-v iet-nam-67-nam-qua-cac-con-so.htm. (Duong, N: Vietnam Economy: 67 years through numbers, VnEconomy)

[12] Nguyễn Đức Thành - Ngô Quốc Thái. 2013. Triển vọng kinh tế Việt Nam nhìn từ giữa năm 2013. Tạp chí Tài Chánh18/07/2013. (Nguyen, Đ.T- Ngo, Q.T. 2013.
Vietnamese economic prospects from the mid of 2013. Finance Magazine).

[13] Minh Ngọc. 2013. Nhóm ngành công nghiệp - xây dựng qua nửa chặng đường. Chính phủ Vietnam (Minh, N. 2013. Industry groups - half way through building, The Government of Vietnam).

http://baodientu.chinhphu.vn/Dau-moc-nua-chang-duong/N hom-nganh-cong-nghiep-xay-dung-qua-nua-chang-duong/1 78862.vgp

[14] Bùi Trinh. 2012. Xác lập lại vai trò kinh tế tư nhân. Báo người lao động.( Bui, T. 2012. Redefining the role of the private sector)

[15] Tổng cục thống kê Việt Nam. 2012. (General Statistics Office of Vietnam)

[16] Bộ Lao động Thương Binh Xã hội - Bộ Nông nghiệp và Phát triển Nông thôn. 2013. Mười năm thực hiện chiến lược toàn diện về tăng trưởng và xóa đói, giảm nghèo ở Việt Nam: Thành quả - Cơ hội - Thách thức. (Ministry of Labor, Invalids and Social Affairs and the Ministry of Agriculture and Rural Development. The conference 28/6/2013 "Ten years of implementing the comprehensive strategy for growth and hunger eradication and poverty in Vietnam: Outcomes Opportunities - Challenges")

[17] Bộ Kế Hoạch \& Đầu Tư. 2013. Hội thảo quốc tế về hợp tác phát triển Việt Nam - Hàn Quốc. (Ministry of Planning \& Investment. 2013. International Conference on Cooperation and Development of Vietnam - South Korea ).

[18] Nguyễn, K. 2013. Cảng cũ quá tải, cảng mới đói hàng, Sài Gòn giải phóng. http://sggp.org.vn/kinhte/2013/1/310521/ (Nguyen Khoa. Old port overloading, new port needs goods, Saigon Liberation)

[19] Đảng cộng sản Vietnam. 2011. Văn kiện Đại hội đại biểu toàn quốc lần thứ XI. trang 173. (Vietnam Communist Party. 2011. Documents of the 11th National Congress, National Politic Publisher, Hanoi, Pp 173).

[20] Nguyễn Thị Ngọc Anh. 2013. Văn hóa kinh doanh ở Việt Nam hiện nay, Nxb Chính trị Quốc Gia Hà Nội. trang 167. (Nguyen, T.N.A. 2013. Business culture in Vietnam today, the National Political Publishing House, Hanoi, Pp 167).

[21] Nguyễn Thị Ngọc Anh. 2013. Văn hóa kinh doanh ở Việt Nam hiện nay, Nxb Chính trị Quốc Gia Hà Nội. trang 167. (Nguyen, T.N.A. 2013. Business culture in Vietnam today, the National Political Publishing House, Hanoi, Pp 167).

[22] Bùi Đình Phong. 2013. Chúng ta đang "thừa" văn minh, thiếu văn hóa. Trung tâm đào tạo, bồi dưỡng nghiệp vụ truyền hình - Đài truyền hình Việt Nam. http://daotao.vtv.vn/gs-ts-bui-dinh-phong-chung-ta-dang-thu a-van-minh-thieu-van-hoa/ (Bui, Đ.P. 2013. We are "excessive" of civilization, but lack "cultural". Training centers, TV professional training - Vietnam Television).

[23] Bộ tài nguyên và Môi trường. 2010. Môi trường và doanh nghiệp qua vụ việc Vedan. (Ministry of Natural Resources and Environment. 2010. Environment and businesses through Vedan case.) 